\title{
РЕЛИГИОЗНОТО ВОСПРИЕМАҢЕ НА ОВЕНОТ КАЈ ДРЕВНИТЕ ЦИВИЛИЗАЦИИ И ВО МАКЕДОНСКАТА НАРОДНА ТРАДИЦИЈА
}

\begin{abstract}
Since the earliest civilizations and continuing to the present, the ram has been seen as the perfect sacrificial animal due to its whiteness and purity. It has been ritually sacrificed to ensure the grace of God in search of salvation and that of loved ones. As such, the objective of this paper is to show the continuity of the ram's religious perception. It has been recorded in the mythologies of ancient civilizations, in religious practices, in folk traditions, and even the archetypal sign of Aries in the circle of the zodiac, known as the "circle of animals." Ancient civilizations used attributes of the mythological deities in various superstitions such as prophecy, purification, and so on. At the same time, they also represent the most important symbol in Christianity, Jesus as the good shepherd.
\end{abstract}

Благодарение на истражувањата на Академик Проф. д-р Петар Хр. Илиевски за Микенската цивилизација, записите на плочките со дешифрираните идеограми со Линеарно-Б писмо ${ }^{1}$ ни даваат увид во стопанското одгледување на овните и овците како ситен добиток ${ }^{2}$ и нивната улога во религиозните обреди кај Микенците. Според П. Хр. Илиевски, добро водената администрација на микенските дворци за активностите од стопанскиот живот, како и бележењата на кноските плочки од D ceријата, не доведуваат до бројката од 100.000 овни и овци распределени во стада, чувани од страна на po-me / poimēn (,„астир“, „овчар“). ${ }^{3}$

${ }^{1}$ Според А. Еванс, Линеарното Б-писмо било во употреба од 1650-1400 г. пр. н. е., а според современите истражувања од 1850 до 1460 или 1440 г. пр. н. е. Илиевски. П. Хр. (2000) 20.

${ }^{2}$ Се смета за прво припитомено животно, околу 11.000 г. пр. н. е. Илиевски. П. Хр. (2000) 111.

${ }^{3}$ Од архивот на Пил и Кнос, во составот на стадата се забележува голема несразмерност меѓу овни и овци, при што бројот на овните е за десет и повеќе пати поголем од бројот на овците. Оттаму според П. Хр. Илиевски, 
Покрај употребата за стопански цели, П. Хр. Илиевски дава увид и на овните кои на плочките со линеарно Б-писмо се заведени и како свети крвни жртви, принесувани на божествата, како на пр. откриените коски од вепар, овца, јагне и млади прасиња во светилиштето на Sевс во Пил. ${ }^{4}$ Бројни се примерите кај Старите Грци за принесување на овни во чест на божествата, на пр. на Seвc, Атена, ${ }^{5}$ а се забележува и замена за крвна жртва преку принесување жртви во вид на колачиња со животинска форма, овен или овца. ${ }^{6}$ Обредните пракси на жртвопринесување се исползувани со колење на добитокот, кој потоа или се печел на огнот во олтарот во светилиштето или пак процесот на печење на жртвуваното животно се извршувал претходно, па потоа печеното месо се принесувало во светилиштето како света крвна жртва, ${ }^{7}$ со цел одоброволување на божествата. Принесувањето на овни како крвни жртви се забележува и кај Балтичките Словени и според Хелмолд (I, 52) на светилиштата: „се собираат луѓе, жени, деца и на своите богови им принесуваат: волови, овни, а исто така и христијани. “8 И денес во македонската народна традиција се забележува чинот на жртвопринесување на јагне, овца или овен за време на празнувањето на селските и куќните слави, каде се собираат возрасни мажи, колат крвна жртва, вол или овен, го подготвуваат и заеднички го јадат јадењето од кое мора секој

дешифраторите сметале дека плочките не даваат реален попис на стадата, туку претставуваат собиран данок во натура, а овните не биле за расплод, туку биле виени, па оттаму и поотпорни на болест, имале поквалитетна волна и покревко месо. Илиевски. П. Хр. (2000) 116-119.

${ }^{4}$ На плочката каде е споменат Diónūsos приносите се бескрвни, мед. Илиевски, П. Хр. (2000) 221-222.

5 Теонимите на женските божества од старогрчкиот пантеон се спомнуваат во микенските натписи кои укажуваат на минојско потекло. Ilievski, P. Hr. (1989) 20. Првото и најпочитуваното место и припаѓа на почитуваната Po-ti-ni-ja (Pótnia), господарка. Čedvik, Dž. (1980) 143. Најчесто се јавува како титула покрај името на Atena, Athānāpotnia, Атена господарка, а називот Pótnia претставува почесна титула која била доделена на повеќе различни божици. Ilievski, P. Hr. (1989) 20-21.

6 Карактеристика на празникот Diasia празнуван во месецот Anthesterion во чест на богот Sевс, се бескрвните жртви (thymataepikhoria) во вид на колачиња со животинска форма, овца или свиња. Крвните жртви меѓу народот се толкувале како монетарна загуба, па затоа биле заменети со колачиња од тесто во облик на жртвуваното животно, кои за време на обредниот чин биле запалувани. Parke, H. W. (1977) 121

${ }^{7}$ Колењето на јагне вообичаено се врши пред изгревот на Сонцето, при што од страна на учесниците се внимава главата на јагнето при чинот на колење да биде свртена кон исток, т.е. кон изгревот на Сонцето. Ковачева, Л. Боцева, Л. (2014)121-122.

${ }^{8}$ Leže, L. (1904) 151-152. 
да проба. ${ }^{9}$ Овните и овците се даваат како крвни жртви, курбан, за време на празнувањето на празниците св. Илија, св. Архангел итн., додека за време на празникот Ѓурѓовден како курбан се дава јагне и тоа да е бело по боја, машко, прво објагнето, најубаво и најкрупно во стадото, освен на Говедар Камен, ${ }^{10}$ каде за жртва се дава црно јагне. ${ }^{11}$ Сакралното значење на овенот како крвна жртва, жртвуван или во кругот на семејството или на колективно ниво во заедницата, во себе содржи одредена социјална димензија и ја докажува кохезијата на групата кон почитување на божествените сили, од кои за возврат се очекува здравје и плодност на луѓето и добитокот.

Јагнето, овцата и овенот од најдалечното минато биле употребувани за претскажувања, преку набљудувањето на внатрешните органи на жртвуваното животно со цел осознавање на иднината. Во старовавилонскиот текст: „Молитвата на боговите на ноќта“, датиран околу 1800 г. пр. н. е. ${ }^{12}$ се спомнува претскажувањето на иднината со помош на пророкување врз јагнешка утроба, метод, кој во текот на II милениум пр. н. е. се сметал за доминантен за претскажување и за пренесување на божествени пораки. И кај Платон единствената пророчка способност која ја имале луѓето е пророкувањето преку набљудување на внатрешните органи на жртвуваното животно, ${ }^{13}$ особено црниот дроб. Претскажување со помош на жртвување на овни се забележува и кај Словените, кои на своите богови за жртва им принесувале волови, овни и Христијани, а потем свештеникот ги преливал со крв за да го разбере пророкувањето. ${ }^{14}$ Претскажувањето со помош на кобилици, овчи плешки се забележува и денес во македонската народна традиција. На пр. во Порече се верува дека доколку при гатањето се гледаат

${ }^{9}$ Филиповић, М.С. (1952) $64-65$.

${ }^{10}$ Говедар Камен во Овчеполието за време на празнувањето на религискиот празник Гуррѓовден е посетен од страна на болни лица и жени неротки. Ковачева, Л. Боцева, Л. (2014) 171.

11 Филиповић, М.С. (1952) 64 -65.

12 Дел од текстот е даден кај Т. Barton, како цитат од Dossin, G. (1935). Barton, Т. (1994) 11.

${ }^{13}$ Dillon, M., Garland, L. (1994) 408.

${ }^{14}$ Според Хелмолд (I, 52): „се собираат луѓе и жени со деца и на своите богови за жртва им принесуваат волови, овни, а исто така и Христијани. Тие сметаат дека боговите особено сакаат христијанска крв. После тоа, свештеникот жртвата ја прелива со крв, за да може подобро да го разбере пророкувањето. Бидејќ́ според кажувањата на многу Словени, злите богови најлесно се мамат со христијанска крв. Кога на тој начин, согласно обичајот, се заврши чинот на принесување на жртва, тогаш, сиот народ седнува на богатата трпеза, јаде, пие, а потем се весели и игра.“ Leže, L. (1904) 151152. 
црвени крвави жили, тогаш „тоа је арно“ и значи напредок и богатство, но доколку „жилата бидет ведра и танка - не чинит, сиромаштија“. 15 Пророкувањето се исползувало и преку набљудување на разни појави, сметани за сигурни предзнаци (semeia), ${ }^{16}$ кои се јавувале во најразлични форми и се толкувале како добри или лоши, независно од волјата на човекот, на пр. раѓањето на еднорог овен на имотот на Перикле, настан посведочен кај Плутарх. ${ }^{17}$

Иако во старогрчката и римската митологија јагнешка кожа е симбол на Јасон и патот до Златното руно, ${ }^{18}$ сепак се забележува дуализам во односот на религиозното восприемање на овчото руно. Од една страна руното било обврзен дел од ритуалните помагала за време на одредени религиозни празници, додека пак од друга, се сметало за култно нечисто. Како обврзен дел од ритуалните пракси се забележува кај Старите Грци за време на празнувањето на: Елевсинските мистерии во процесија од Атина до Елевсина, ${ }^{19}$ каде мистите (Mystai) на главите биле украсени со венци од митра, а во рацете носеле снопови гранчиња од митра врзани со волна (bakchoi) кои ги нишале во ритам; ${ }^{20}$ Pyanepsia, ${ }^{21}$ каде деца во процесија во рацете носеле Eiresione, маслинови гранчиња врзани со волна (eiros) и свети гранчиња со лавор посветени на Аполон, долги 2-3 педи и декорирани со овошје и предмети кои симболизирале плодност: харфи, ${ }^{22}$ чаши и гранки од винова лоза; ${ }^{23}$ Khalkeia, ${ }^{24}$ ден на кој свештеничките свечено

${ }^{15}$ Обремски, J. (2001)183.

16 Фласелјер, Р. (2002) 231.

${ }^{17}$ Кај Плутарх е дадено различното толкување меѓу пророкот Лампон и Анаксагора, а поврзано со раѓањето на еднорог овен на имотот на Перикле. Плутарх, Перикле, 6.

${ }^{18}$ Хол, А. С. (2013) 55.

${ }^{19}$ Кога се носела тајната статуа на која бил претставен ликот на младиот бог Iakchos, елевсинското име на Богот Дионис/Бакх. James, Е. О. (1961) 141 .

${ }^{20}$ Мистите се учеснички кои за прв пат учествувале во празнувањето на Големите Елевсински мистерии. James, Е. О. (1961) 141.

${ }^{21}$ Кој се славел во време на доцна есенска берба на овошје, кога се барало благослов за есенските посеви. Parke, H. W. (1977) 75.

22 Харфата се употребувала во Сумер од пред 3500 г. пр. н. е, во Египет пред 2600 г. пр. н. е., а сведоштвата за нејзината употреба на овие простори датираат од околу 600 г. пр. н. е. Дуев, Р. (2009) 45.

${ }^{23}$ Фласелјер, Р. (2002) 56, 214.

${ }^{24}$ Името на празникот е изведено од старогрчките зборови khalkos, бакари khalkeis, ковач и сугерира на празник празнуван од страна на ковачите, со што упатува на неговото оригинално потекло од Бронзеното доба и се поврзува со богот на ковачите Хефајст. Ковачева, Л. (2012) 100-101. 
започнувале со поставување овча волна на разбој, со цел на божицата Атена да и исткаат нова наметка (peplos) која се ткаела следните 9 месеци и се презентирала за време на празнувањето на празникот Panathenaia ${ }^{25}$ итн. Негативниот аспект на руното (т.е. овчата волна) се забележува во верувањата на Старите Грци, според кои свештениците морале да носат облека од лен, кој се сметал за култно чист, бидејќи не бил од животинско потекло. Волната воопшто не се употребувала бидејќи била земена од животинско тело и кога е одвоена од телото е мртва, а бидејќи мртовецот е нечист и волната е нечиста, па оттаму во целост била исклучена. Боговите ја носеле за време на дивинизација и магија, па поради тоа смртниците ја сметале за култно нечиста. ${ }^{26}$ Волната се употребувала и во обичајот за спуштање на смртникот на земја, обичај забележан кај многу народи, а постоел и на територијата на Стара Грција, Србија и Македонија. Се состоел во тоа што кога некому ќе му се приближел смртниот час, го облекувале во ново руво, го спуштале долу на земја на која имало послано рогозина и внимавале да не биде покриен со „нешто волнено, бидејќи во таа волна може да има и волна од пцовисан добиток“ и во тој случај умирањето нема да биде воопшто лесно. ${ }^{27}$

Овчото руно било застапено и во чинот на прочистување. На пр. за време на празничниот ден Pompaia во чест на Seвс Meilikhios, ${ }^{28}$ имало процесија во која се движеле исклучиво свештени лица кои со себе го носеле овчото руно, добиено преку колење на овца и отстранување на кожата од телото, почитувано како свето руно кое го жртвувале на Seвc Meilikhios. Како неизоставен дел од обредните церемонии било индивидуалното прочистување на оние граѓани кои се сметале за нечисти. Чинот на прочистување се состоел или од можноста на нечистиот да застане со својата лева нога врз светото руно, кое имало моќ да ја апсорбира сета нечистотија од човекот или преку можноста на нечистиот да седне босоног врз руното, со покриена глава, при што чинот на прочистување го извршувал свештеникот со обредот на провејување (likhnon). ${ }^{29}$

25 На наметката биле претставени митолошки мотиви од гигантомахијата, кои изобилувале со светли тонови на жолта и сина боја. Ковачева, Л. (2012) 101.

26 Чајкановић, В. (1924) 139-142.

${ }^{27}$ Со цел човекот при умирачката да не се мачи и полесно да ја испушти душата, се верувало дека доколку смртникот се спушти на „гола земја“, ќе добие прошка од земјата, ќе се ослободи од гревовите, полесно ќе умре и душата полесно ќе замине на небото. Ђorђeviћ, R. Т. (1938) 470.

${ }_{28}$ Месецот е именуван според епитетот на Seвc Maimaktes (овчо руно). Parke, H. W. (1977) 95.

${ }^{29}$ Ковачева, Л. (2012) 103. 
Претставата на Овен се забележува и во зодијачките знаци, каде старогрчките и римските астролози ${ }^{30}$ водени од теоморфизмот, дел од нив ги идентификувале со одредени животни. ${ }^{31}$ Овенот е првиот архетипски знак во хороскопот кој ги контролира органите кои се центар на индивидуата за духовна и физичка енергија, па оттаму овој знак се смета за центар на космичките сили. ${ }^{32}$ Присуството на хороскопот и симболичкото толкување на хороскопските знаци се забележуваат во записите на епископот Зенон од Верона, кој починал во 380 година. Тој во своите записи ја завел проповедта на новите, тукушто крстени христијани, кои за да преживеат го понудиле христијанизираниот хороскоп. Во хороскопот, Зенон хороскопските знаци на Овен и Бик симболички ги поврзал со Исус како жртвена жртва, т.е. јагне и теле. Според Т. Бартон, не постојат сведоштва за приемот на овој необичен запис на Зенон, како во црковните редови, така и во народните традиции. Но сепак, познато е дека неговите дела до првата половина од VI век сѐ уште биле присутни на територијата на Галија. ${ }^{33}$ На територијата на Р. Македонија, претстава на хороскопот со хороскопскиот знак на овен во византиското монументално сликарство се наоѓa во нартексот на црквата Св. Архангел Михаил во Лесново, од 1341 година. ${ }^{34}$

${ }^{30}$ Астрологијата како предмет за потсмев е дадена во новелата Satyricon на Петрониј, напишана во времето на Нерон. Авторот со потсмев пишува за полу-образованиот ново богаташ, кој сакајќи да ги импресионира своите гости ги повикал во својот дом на отмена вечера. При дискусија за хороскопските знаци, домаќинот им посочил дека оние лица, родени под хороскопскиот знак Овен, во животот ќе бидат или сопственици на овци и ќе имаат многу волна или пак, ќе станат големи кавгаџии. Petron. Satyricon, 39. Според Г. Лак новелата Satyricon на Петрониј, претставува вид на пародија на „кралската“ традиција на сериозни астролози. Luck, G. (2006) 376.

${ }^{31}$ Luck, G. (2006) 384.

${ }^{32}$ Cirlot, J. E. (1962) 18-19.

${ }^{33}$ Симболичкиот дуализам се забележува во поврзувањето на хороскопскиот знак Близнаци со Стариот и Новиот завет; со хороскопските знаци Рак и Јарец, на симболички начин го прикажал нивото на човечкиот порок; симболичкото толкување на хороскопскиот знак Девица која ја раѓa Вагата, според Зенон, соодветствува со раѓањето на Исус од страна на Дева Марија, како носител на правдата; хороскопскиот знак Лав го асоцирал со Јуда, лавмладенче, но и со Христовото воскресение; хороскопскиот знак Скорпија, кај Зенон потсетува на преминот каде што Исус дал овластување да се гази преку змии и скорпии, па оттаму, според него се поврзува со ѓаволот; хороскопскиот знак Стрелец, поради присуството на огнените стрели, потсетува на описот на Св. Павле; хороскопскиот знак Водолија го поврзал со крштевањето; додека со хороскопскиот знак Риба го прикажал единството, т.е. обединувањето на Евреите и незнабожците во Христа. Barton, Т. (1994) 71.

34 Тутковски, М. (2010) 278. 
Симболиката на овенот како позитивен и машки знак: жесток, мажествен, инстиктивен и моќен, сили кои го будат човекот и светот и обезбедуваат продолжување на животниот циклус, ${ }^{35}$ се симболички слики потврдени во бројни митолошки приказни за обожувањето на богот на овенот, како бог на создавањето. На пр. во египетската митологија, симболот на Амон Ра е овенот $^{36}$, па оттаму е и неговата претстава со глава на овен со рогови, ${ }^{37}$ а се издвојува и сфингата претставена со тело на лав и

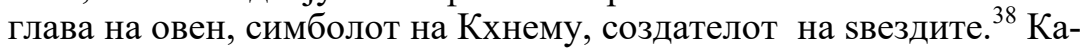
ко сведоштва за обожувањето на овенот на територијата на Македонија се бронзениот шлем од архајскиот период, на кој на двете предни страни има претстава на овен со рогови ${ }^{39}$ и импозантниот примерок на белезица со завршетоци во вид на овнови глави, датирана од IV век пр. н. е., ${ }^{40}$ обете откриени во некрополата на Горна Порта во Охрид, што не упатува на претставата на глава на овен со рогови на Sевс-Амон, многу почитувано божество меѓу античките Македонци, ${ }^{41}$ Во старогрчката митологија како носач на овен е прикажан Хермес Криофор, кој носејќи овен на своите раменици околу градот успеал да ја оддалечи сточната зараза, претстава која во голема мера наликува на бројните христијански претстави на „Добар Пастир“ кој врз своите раменици носи овен или јагне. ${ }^{42}$ Бројните пасторални обреди во митовите, преку кои народите му укажувале почит на богот на овенот, се сметаат за извори на верувањето за Христос, како добар пастир, ${ }^{43}$ кој според П. Хр. Илиевски , ја поставил љубовта за основа на меѓучовечките односи. “44 Оттаму, според В. Митевски, Новиот завет станал своевидно етичко учење, ${ }^{45}$ кое морало да се преведе

${ }^{35}$ Шевалие, Ж., Гербран, А. (2005) 701.

${ }^{36}$ Wilkinson, R. H. (2003) 204-209.

${ }^{37}$ Cirlot, J. E. (1962) 18-19.

${ }^{38}$ Хол, А. С. (2013) 82.

${ }^{39}$ Куман, П.( 2013) 454.

40 Блевска, С. (2013) 708.

41 За култот на Sевс-Амон во Македонија и за почитта која ја уживал меѓу античките Македонци, укажуваат посетите на Филип на светилиштето на Амон во Теба, Бојотија, каде се наоѓала статуата на ова божество посветена од Пиндар (Paus., IX, 16,1), како и принесувањето свети жртви од страна на Филип во светилиштето на Амон во Македонија, лоцирано во градот Афитис. Плутарх, 7, Превод од старогрчки јазик Саракински, В., коментари Проева, Н. (2008) 185.

42 Eisler, R. (1921) 53.

${ }^{43}$ Cirlot, J. E. (1962) 18-19.

${ }^{44}$ Илиевски, П. Хр., Гоцевски, Т. (2002) 16.

${ }_{45}$, Кој од вас, ако има сто овци, и ако загуби само една од нив, нема да ги остави деведесет и деветте во пустина и нема да оди да ја бара загубе- 
на разбирлив јазик, како за необразованиот верник, така и за новиот веќе образуван верник од класичната античка култура. ${ }^{46}$ За раната застапеност на овцата во христијанските мотиви на територијата на Македонија, сведочи мозаикот на подот на првата ранохристијанска градба откриена на локалитетот Плаошник во Охрид, датирана во првата деценија на VI век. ${ }^{47}$

Заклучок: Неоспорен е фактот за значењето на овенот за стопанските цели, доследно образложени во описите за микенската цивилизација кај Академик П. Хр. Илиевски, како и неговото религиозно восприемање кај древните народи. Неспоредлива е неговата застапеност во религиозните пракси како свет жртвен дар со цел одоброволување на божествата, суеверните пракси со цел претскажување на иднината, прочистување со цел ослободување од гревовите итн., како и неговата улога како прв архетипски знак во хороскопот. Преку доделувањето на неговите атрибути на божествата во митолошките приказни, па до неговото прифаќање како највозвишен симбол во христијанството преку претставата на Исус како добар пастир, јасно се забележува континуитетот на неговото восприемање низ просторот и времето, од најдалечните цивилизации до денешното современо општество, како симбол на жртвувањето, како спасение за себе и за своите најблиски.

\section{ЛИТЕРАТУРА}

Barton, T. (1994) Ancient astrology, London \& New-York: Routledge.

Блажевска, C. (2013) Раната антика и хеленистичкиот период во Македонија, Милениумско културно-историски факти, Том 2, Скопје.

Dillon, M., Garland, L. (1994) Ancient Greece, Social and Historical Documents from Archaic Times to the Death of Socrates (c.800-399 BC), Routledge, London and New York.

Дуев, Р. (2009) Музиката во микенскиот свет и Хомер, Матица, Скопје.

Eisler, R. (1921) Orpheus -The Fischer, Comparative studies in Orphic and Early Christian Cult Symbolism, Historical Institute at the Vienna University, etc, London.

ната, сѐ додека не ја најде? А откако ќе ја најде, ќе ја крене на рамена радосен; и кога ќе дојде дома, ќе повика пријатели и соседи, и ќе им рече: ‘Радувајте се со мене, зошто ја пронајдов загубената овца!' Ви велам дека така и на небото ќе биде поголема радост за еден грешник кој се кае, отколку за деведесет и девет праведници, кои што немаат потреба од покајание.“ Евангелие по Лука, 15: 4-7, Новиот Завет (2006) 96.

${ }^{46}$ Митевски, В. (2011) 31.

47 Тутковски, М. (2014) 154. 
Ilievski, Hr. P. (1989) „Doprinos linearnih B tekstova u rasvetljavanju Grčke religije kasne bronzene epohe“, Godišnjak, Knjiga XXVII, Sarajevo.

Илиевски, Хр. П. (2000) Животот на Микенците во нивните писмени сведоштва, Скопје.

Илиевски, Хр. П., Гоцевски, Т. (2002) Христијанството и мирот. Мирот и христијанството, Македонска ризница, Скопје.

James, E. O. (1961) Comparative religion, Methuen and CoLtd., London.

Ковачева, Л. (2012) Симболизмот во празниците кај Старите Гричи и во македонската народна традиција, Матица, Скопје.

Ковачева,Л., Боцева, Л. (2014) Речник на македонските народни празници, обичаи $u$ верувањ $а$, Завод за културно и духовно наследство, Скопје.

Кузман, П. (2013) Архајски период во Македонија, Милениумско културно-историски факти, Том 1 , Скопје.

Leže, L. (1904) Slovenska Mitologija, Beograd.

Luck, G. (2006) Arcana Mundi, Magic and the Occult in the Greek and Roman Worlds, A Collection of Ancient Text, Translated, Annotated and Introduced by Georg Luck, The Johns Hopkins University Press, Baltimore.

Митевски, В. (2011) Античката философија и византија, Матица, Скопје.

Обрембски, J. (2001). Фолклорни и етнографски материјали од Порече, Книга I, Редакција Вражиновски, Т., Составиле Вражиновски, Т., Јовановска, С., Караџоски, В., Скопје.

Parke, H. W. (1977) Fetivals of the Athenians, Aspects of Greek and Roman Life, Cormel Univeristy Press, Ithaca, NewYourk.

Плутарх (2008) Напоредни животописи. Ликови од историјата на древна Македонија, Historia Antiqua Macedonica, Книга 7, превод од старогрчки јазик Саракински, В., коментари Проева, Н., Скопје.

Свето писмо, Библија, (2006) Новиот завет, МПЦ, Скопје.

Тутковски, М. (2010) „Претставите на зодијакот во византиското и поствизантиското сликарство во Р. Македонија“. Патримониум, Каламус, Год. 3, бр. 78, Скопје.

Тутковски, М. (2014) Ранохристијанските мозаици од Охрид, Каламус, Скопје.

Филиповић, М. С. (1954) Основни карактер и структура народног веровања у источном делу Југославије, Зборник Матице Српске, Нови Сад.

Фласелјер, Р. (2002) Гриија во времето на Перикле, Скопје.

Хол, А. С. (2013) Речник на значајни симболи во нивната хебрејска, паганска и христијанска форма, Скопје.

Чајкановић, В. (1924) Српски етнографски зборник, Живот и обичаји народни, Књига 13, Студије из религије и фолклора, Београд.

Cirlot, J. E. (1971) Dictionary of Symbols, Routledge \& Kegan Paul Ltd, Second edition, London.

Čedvik, Dž. (1980) Mikenski svet, Beograd.

Ђorђeviћ, Р. Т. (1938) „Прилози за књижевност, језик, историју и фолклор“,Полагање смртника на земьу, Къига XVIII, Свеска 1-2, Београд.

Шевалие, Ж., Гербран, А. (2005) Речник на симболите, Митови, соништа, обичаи, гестови, облици, ликови, бои, броеви, Табернакул, Скопје. 
Wilkinson, R. H. (2003) The Complete Gods and Goddesses of Ancient Egypt, Thames $\&$ Hudson, Ltd London. 